\title{
TWO-POINT OSTROWSKI INEQUALITY
}

\author{
M. MATIĆ AND J. PEČARIĆ
}

Abstract. A generalization of a classical Ostrowski inequality is proved. As a consequence, an improvement of a recent result of Barnett and Dragomir is given.

Mathematics subject classification (2000): 26D15.

Key words and phrases: Integral inequalities, Ostrowski inequality.

\section{REFERENCES}

[1] N. S. BARNETT AND S. S. DRAGOMIR, Issues of estimation in the monitoring of constant flow continuous streams, RGMIA, Research report collection, Vol. 2, No. 3 (1999), pp. 275-282

[2] D. S. Mitrinović, J. PEČARIĆ AND A. M. FINK, Inequalities involving functions and their integrals and derivatives, Kluwer Acad. Publ., Dordrecht, 1991.

[3] A. OsTROWSKI, Uber die Absolutabweichung einer differentierbaren Funktionen von ihren Integralmittelwort, Comment. Math. Helv., 10(1938), 226-227. 